Research Article

www.ijrap.net

\title{
A CLINICAL STUDY TO COMPARE THE ROLE OF JALADHARA AND SANKHAPUSPI RASAYAN IN THE MANAGEMENT OF CHITTODVEGA (ANXIETY DISORDERS) \\ Ranjip Kumar Dass*
}

Assistant Professor, M.S.M. Institute of Ayurveda, B.P.S. Mahila Vishwa Vidyalaya, Khanpur Kalan, Sonipat, Haryana, India

Received on: 14/08/12 Revised on: 21/10/12 Accepted on: 11/11/12

\author{
*Corresponding author \\ E-mail: drranjipayu@yahoo.co.in \\ DOI: $10.7897 / 2277-4343.03641$ \\ Published by Moksha Publishing House. Website www.mokshaph.com \\ All rights reserved.
}

\section{ABSTRACT}

Chittodvega is a Manasa Vikara described by Charak. It has been considered as a perfect word for highlighting the status of anxiety, which is produced due to vitiation of Raja and Tama. In addition Prana, Udana, Vyana Vayu; Sadhaka Pitta; and Tarpaka Kapha are also provocated factors in it. On the basis of these considerations it can be postulated that Chittodvega is a minor mental disorder. In modern parlances also, the neurotic disorders which include anxiety disorders are considered as minor mental disorder in comparison to major mental condition like schizophrenia etc. Beneficial action of Shirodhara in the management of anxiety disorder has been reported. Acharya Charaka has advised to use Medhya Rasayana drugs for the mental disorders, especially for the promotion of Medha. Sankhapuspi (Convolvulus pluricaulis) has been considered best amongst the Medhya Rasayana drugs. Here in this study the total 36 patients of Chittodvega (Anxiety disorders) were randomly divided into two groups: 1) Group-J: The patients of this group were subjected to Jaladhara for 30 minutes daily in the morning between 8:30 to 11:00 AM for 6 weeks with a gap of 1 week after completion of three weeks course of Jaladhara. 2) Group-SR: The Patients of this group were administered 3 gms powders of Sankhapuspi Rasayana three times a day orally with water for 6 weeks. It can be concluded that Jaladhara gave better relief in panic attack and phobic disorder while Sankhapuspi Rasayana is more useful in generalized anxiety disorder. Results of the study are encouraging and these two therapies i.e. Jaladhara and Sankhapuspi Rasayana may become first line treatment of Chittodvega (Anxiety disorders).

Key words: Shirodhara, Medhya Rasayan, Jaladhara, Chittodvega, Sankhapuspi

\section{INTRODUCTION}

Ayurveda - an eternal science of healthy living treasures deals with physical, psychological and spiritual well being of the human being and covers all the aspect of human life. It is not a materialistic science but a philosophical and fact full truth, which enhanced by our great ancient sages, through their experience, logic and power of wisdom.

Human life is considered as the invaluable opportunity to achieve the prime goals of life viz. Dharma, Artha, Kaama and Moksa. To achieve all these things, one needs a healthy and calm life. Whole ancient society tried to achieve all four prime goals of life, so that they had a smooth, sound, safe, assured, steady and healthy life style. On the other hand today every one trying to gain good financial status and to fulfill all the physical desires, today's metaphysical society is facing unsteady, weakened, hard and everyday changing life style. As a gift of this life style, almost everyone appears to be stressed and confused; these reflection can lead to mental disability like Chittodvega i.e. anxiety disorders.

With the advancement of modern science, human life becomes very speedy and more stressful. So psychiatric illness are broadening its sphere today, out of which anxiety disorders are most common wide spread psychiatric disease affecting human kind today in all over the world in all ethnic groups.

In Ayurveda various psychological disorders are mentioned, which show some similarity with the anxiety disorders. Chittodvega ${ }^{1}$ seems to be nearest term for anxiety disorders, which is one of the psychological disorder described by Charaka. Various texts have described many terms related to mental status viz. Chittavibhramsa, Chittanasa, Chittavibhrama, Chittaviparyaya, Anavasthita Chitta etc. But Chittodvega ${ }^{1}$ seems to be more appropriate for the anxiety disorder. The etiology of Chittodvega clearly indicates the anxious status of mind.

In modern parlances also, the neurotic disorders, which include Anxiety Disorders ${ }^{2}$ are considered as minor mental disorder in comparison to major mental entities like schizophrenia etc.

Anxiety is a universal experience, which has an important protective function in the face of danger. It becomes morbid when symptoms are out of proportion to external circumstances or if they persist long after a threatening situation has been averted. However, there is no clear distinction between the features of normal and pathological anxiety, but in pathological condition, the anxiety is the chief symptom and acting through the autonomic nervous system, produces all kinds of visceral symptoms.

Being an alarming problem it needs effective and safe treatment. Modern therapeutics though have a spectrum of the drugs for management of this disease, they are having serious side effects and habit forming nature. Therefore there is a wide scope of research to find out a safest remedy or non-pharmacological approach from Ayurveda for the management of this disease.

Beneficial action of Shirodhara ${ }^{3}$ in the management of anxiety disorder has been reported, but in the previous study medicated oil was used for Shirodhara. As the 
medicated oil is very costly and whole society cannot consummate it for the treatment of this disease, So Shirodhara with water (Jala) was selected for this study to evaluate its role in the management of Chittodvega.

Acharya Charaka has advised to use Medhya Rasayana ${ }^{4}$ drugs for the mental disorders, especially for the promotion of Medha. Sankhapuspi ${ }^{5}$ (Convolvulus pluricaulis) has been considered best amongst the Medhya Rasayana drugs. But little effort has been made to establish its role in management of Chittodvega (anxiety disorders), so this drug was also selected for this study.

\section{MATERIALS AND METHODS}

The course of treatment which cures the original disease but produces some other kind of complications is not the correct line of treatment, the correct one is that, which cures but does not provoke ${ }^{6}$.

The anxiety disorders looks very simple but if we measure impairment of social and occupational functioning, people with this disease are significantly worse off than people with any other chronic medical illness. The modern medical treatment of this disease requires long term use of sedative, hypnotic and anxiolytic drugs, which may lead to the side effects like drowsiness, impaired motor function, loss of memory, allergic reaction, and anti social behavior. According to Dr. Malcom Lader, a Professor at the Institute of Psychiatry, which is a part of the Maudsley Hospital London (UK), when patients try to lower such a drugs i.e. benzodiazepines and when they try to discontinue the drug, altogether as many as $25-30 \%$ of them experience severe withdrawal symptoms. Those withdrawal symptoms are worse than the symptoms of main disorder. Hence, this study was undertaken with the following aims:

\section{Aims and Objectives}

- To study the etio-pathogenesis of Chittodvega vis-àvis Anxiety Disorders on the Ayurvedic terms.

- To evaluate the role of Jaladhara in the management of Chittodvega (Anxiety Disorders.)

- To evaluate the role of Sankhapuspi in the management of Chittodvega (Anxiety Disorders).

- To compare that, which of the above therapy is better for the management of Chittodvega (i.e. Anxiety disorders)

\section{Source of Formulation}

The patients of Chittodvega were selected from O.P.D. and I.P.D. sections of Dept. of Panchakarma, M.S.M. Institute of Ayurveda, B.P.S. Mahila Vishwavidyalaya, Khanpur Kalan, Sonipat (Haryana). The Permission for clinical trial in M.S.M.Institute of Ayurveda and Hospital was taken with letter no. Inst./Ayu./11/2447 dated 24.05.11. Detailed history and physical and mental examinations were done on the basis of specialized proforma prepared for this purpose. Diagnosis was done on the basis of following criteria.

\section{Criteria for diagnosis}

1. DSM IV ${ }^{7}$ diagnostic criteria for various anxiety disorders were primarily adapted.
2. All the signs and symptoms of Chittodvega and anxiety disorder as well as mentioned in Hamilton scale were taken into consideration.

3. Pulse, Respiration and Blood Pressure were checked to assess the present condition of the disease. Routine blood, urine and stool examinations were performed to exclude other pathogenesis.

\section{Plan of Study}

36 patients of Chittodvega (Anxiety disorders) were randomly divided into the following 2 groups:

\section{Group J}

The Patients of this group were subjected to Jaladhara ${ }^{8}$ for 30 minutes daily in the morning between 8:30 to 11:00 AM for 6 weeks with a gap of 1 week after completion of three weeks course of Jaladhara.

\section{Group SR}

The Patients of this group were administered 3 gms powders of Sankhapuspi Rasayana three times a day orally with water for 6 weeks. During the treatment, the patients were asked to take their routine diet.

\section{Source of Sankhapuspi Rasayana}

The Sankhapuspi Churna and Kasaya along with Sankhapuspi Rasayana were procured from Gurukul Pharmacy, Sonipat, Haryana, India. Here the whole plant (Panchaanga) of Sankhapuspi was used. At first the dry powder of Sankhapuspi was made and then decoction (Kasaya) was made by using 1 part coarse powder of Sankhapuspi and 4 part water boiled up to $1 / 4^{\text {th }}$. The Sankhapuspi Churna was then processed with 7 Bhavana of Sankhapuspi Kasaya to make Sankhapuspi Rasayan and packed in small polythene bags.

\section{Criteria for assessment}

The patients of Jaladhara group were examined daily and the patients of Sankhapuspi Rasayana group were given medicine for 7 days and at the end of the week, their improvement in signs and symptoms was noted. Improvement in all the signs and symptoms as per Hamilton's anxiety rating scale was assessed.

Signs and symptoms mentioned in Hamilton scale were assessed by adopting the following scoring system.

$\begin{array}{ll}\begin{array}{l}\text { Degree of anxiety } \\ \text { Pathological condition }\end{array} & \text { Scoring } \\ \text { None } & 0 \\ \text { Mild } & 1 \\ \text { Moderate } & 2 \\ \text { Severe } & 3 \\ \text { Severe, grossly disabling } & 4\end{array}$

Other chief complaints like phobia, obsession, compulsion, etc. were scored as per above pattern. Pulse, respiration and blood pressure of all the patients of Jaladhara group were recorded before and after the Jaladhara everyday and in Sankhapuspi Rasayana group, they were recorded at the terminal of one week.

\section{Overall effect of therapy}

Overall effect of the therapy was assessed in terms of complete remission, marked improvement, moderate improvement, improvement and unchanged by adopting the following criteria.

1) Complete remission: $100 \%$ relief in the Hamilton's anxiety rating scale was considered as complete remission. 
2) Marked improvement: More than $75 \%$ reduction in the score of the Hamilton's anxiety rating scale was taken as marked improvement.

3) Moderate improvement: $50 \%$ to $75 \%$ improvement in the Hamilton's anxiety scoring pattern was recorded as moderate improvement.

4) Improvement: $25 \%$ to $50 \%$ improvement in the Hamilton's anxiety rating scale was considered as improvement.

5) Unchanged: Less than $25 \%$ reduction in the Hamilton's anxiety rating scale was noted as unchanged.

Table 1: Groups Wise Distribution of 36 Patients of Chittodvega

\begin{tabular}{|c|c|c|c|c|}
\hline Types & \multicolumn{3}{|c|}{ No. of Patients } & $\%$ \\
\hline Complete & Group J & Group SR & Total & \\
\hline L. A. M. A. & 8 & 12 & 20 & 55.5 \\
\hline
\end{tabular}

Table 2: Effect of Jaladhara on Hamilton Scale in the 8 Patients of Chittodvega

\begin{tabular}{|c|c|c|c|c|c|c|c|}
\hline \multirow{3}{*}{ Group J } & \multicolumn{2}{|c|}{ Mean Score } & $\begin{array}{c}\% \\
\text { M.T. }\end{array}$ & $\begin{array}{c}\text { S.D. } \\
( \pm)\end{array}$ & $\begin{array}{c}\text { S.E. } \\
( \pm)\end{array}$ & t & P \\
\cline { 2 - 8 } & B.T. & A.T. & Relief & $( \pm)$ & \\
\cline { 2 - 9 } & 2.58 & 0.84 & 67.49 & 0.34 & 0.12 & 14.42 & $<0.001$ \\
\hline
\end{tabular}

Table 3: Overall Effect of Two Courses of Jaladhara in the 8 Patients of Chittodvega

\begin{tabular}{|c|c|c|}
\hline \multirow{2}{*}{ Pverall Effect } & No. of Patients & \multirow{2}{*}{$\%$} \\
\cline { 2 - 2 } & Group J & \\
\hline Complete remission & 0 & 0 \\
\hline Marked improvement & 1 & 12.5 \\
\hline Moderate improvement & 7 & 87.5 \\
\hline Improvement & 0 & 0 \\
\hline Unchanged & 0 & 0 \\
\hline
\end{tabular}

Table 4: Effect of Sankhapuspi Rasayana on Hamilton Scale in the 12 Patients of Chittodvega

\begin{tabular}{|c|c|c|c|c|c|c|c|}
\hline \multirow{3}{*}{$\begin{array}{c}\text { Group } \\
\text { SR }\end{array}$} & \multicolumn{2}{|c|}{ Mean Score } & \multirow{2}{*}{$\begin{array}{c}\% \\
\text { Relief }\end{array}$} & \multirow{2}{*}{$\begin{array}{c}\text { S.D. } \\
( \pm)\end{array}$} & \multirow{2}{*}{$\begin{array}{l}\text { S.E. } \\
( \pm)\end{array}$} & \multirow[t]{2}{*}{$\mathrm{t}$} & \multirow[t]{2}{*}{$\mathrm{P}$} \\
\hline & B.T. & A.T. & & & & & \\
\hline & 2.40 & 0.69 & 72.06 & 0.40 & 0.11 & 15.05 & $<0.001$ \\
\hline
\end{tabular}

Table 5: Overall Effect of Sankhapuspi Rasayana in the 12 Patients

\begin{tabular}{|c|c|c|}
\multicolumn{2}{|c}{ of Chittodvega } \\
\hline Overall Effect & No. of Patients & \multirow{2}{*}{$\%$} \\
\cline { 2 - 2 } & Group SR & \\
\hline Complete remission & 0 & 0 \\
\hline Marked improvement & 5 & 41.7 \\
\hline Moderate improvement & 7 & 58.3 \\
\hline Improvement & 0 & 0 \\
\hline Unchanged & 0 & 0 \\
\hline
\end{tabular}

\section{OBSERVATIONS AND RESULTS}

Total 13 patients were registered in Jaladhara group (Group J); amongst 8 patients completed the treatment and 5 patients were leave against medical advice. In Sankhapuspi Rasayana group (Group SR) 12 patients completed the treatment and 11 patients were leave against medical advice. (Table 1)

In this way, total 36 patients were registered for this study, amongst 20 patients completed the full course of the treatment, whereas 16 patients were leave against medical advice (L.A.M.A.).

The Table 2 exhibits that before Jaladhara mean scoring of Hamilton scale was 2.58 and after completion of course it reduced to 0.84 . This reduction of $67.49 \%$ was statistically significant $(<0.001)$.

The Table 3 shows that out of 8 patients of Jaladhara group (Group J), only 1 patient $(12.5 \%)$ gained marked improvement and remaining 7 patients $(87.5 \%)$ showed moderate improvement. In this group 5 patients were dropped out.

The Table 4 denoted that before treatment mean scoring of Hamilton scale was 2.40 , which reduced to 0.69 after treatment. This $72.06 \%$ relief was statistically significant $(<0.001)$.

The Table 5 exhibits that total 12 patients of Sankhapuspi Rasayana group (Group SR) have completed the full course. Out of 12 patients, 5 patients $(41.7 \%)$ gained marked improvement and remaining 7 patients $(58.3 \%)$ were having moderate improvement. In this group 11 patients left the treatment and were reported as dropped out.

\section{DISCUSSION}

The outcome of the study was highly encouraging with both therapies. Jaladhara provided $67.49 \%$ reduction in Hamilton scale and Sankhapuspi Rasayana provided $72.06 \%$ relief in Hamilton scale. The study also proved that $12.5 \%$ patients gained marked improvement and $87.5 \%$ patients showed moderate improvement in Jaladhara group, and in Sankhapuspi Rasayana group, $47.7 \%$ patients showed marked improvement and 58.3\% patients showed moderate improvement. Therefore, overall effect of Sankhapuspi Rasayana for the management is better than Jaladhara.

\section{Probable Mode of Action of Jaladhara}

Jaladhara is continuous pouring of fresh taped water to the forehead and is an effective treatment for reducing stress and expanding one's consciousness. The mind, body and spirit are intimately connected, and Jaladhara by calming the stressful mind, relaxes the entire physiology. Imbalance of Prana, Udana and Vyana Vayu, Sadhaka Pitta and Tarpaka Kapha can produce stress and tension. Jaladhara re-establishes the functional integrity between these three subtypes of Dosha through its mechanical effect. Sahasra Chakra is the seat of pituitary and pineal gland. As we know, the pituitary gland is one of the main glands of the endocrine system. Jaladhara stimulates the pituitary gland by its penetrating effect, which helps in bring the hormonal balance. In relation to the Doshas, Chittodvega is mainly produces due to Vata and Pitta Dosha. Jaladhara have a calming and centering effect for Vata Dosha. Jaladhara also provided coolness to reduce Pitta Dosha. Hence, Jaladhara have a calming, penetrating and cooling effect, which are very useful in treating Chittodvega.

Probable Mode of Action of Sankhapuspi Rasayana

Sankhapuspi Rasayana was made from Sankhapuspi Churna processed with 7 Bhavana of Sankhapuspi Kwath. Thus, Sankhapuspi Rasayana has more potency than simple Sankhapuspi Churna. The results of present study showed that Sankhapuspi Rasayana relieves anxiety, irritability, restlessness, and inability to relax due to its anxiolytic effect. Sankhapuspi improves lack of concentration and memory due to its Medhya effect. Sankhapuspi have a sedative effect, which gives good healthy sleep. Sankhapuspi have been mentioned as a Rasayana in Charaka Samhita, so that it gives freedom from fatigueness. Sankhapuspi is also a proven hypotensive drug (Chaturvedi et al, 1966) and this study also proved that Sankhapuspi also decreases blood 
pressure and pulse rate due to its anti stress effect. At Doshic level, Sankhapuspi reduces Vata due to its Madhura Vipaka and Snigdha, Picchila Guna reduces Pitta due to its Sheeta Virya and due to its Tikta Rasa, it reduces Kapha Dosha, but is especially effective on Vata and Pitta Dosha.

\section{CONCLUSION}

The comparison of the results of both the group shows that Jaladhara provided better relief in loss of interest, depression, fear, phobia, obsession, compulsion, chest pain/discomfort, breathlessness, muscular pain and exhaustion. While Sankhapuspi Rasayana provided comparatively improvement than Jaladhara in anxiety, irritability, inability to relax, lack of concentration, disturbed sleep, loss of memory, palpitation and headache, dryness of mouth, upset stomach and restlessness.

Hence, it can be stated that Jaladhara gave better relief in panic attack and phobic disorder while Sankhapuspi Rasayana is more useful in generalized anxiety disorder. Results of the study are encouraging and these two therapies i.e. Jaladhara and Sankhapuspi Rasayana may become first line treatment of Chittodvega (Anxiety disorders).

\section{ACKNOWLEDGEMENT}

I acknowledge my gratitude to Principal and Dean, M.S.M. Institute of Ayurveda and Hospital, Khanpur Kalan for their support in providing scope in the OPD and IPD of Panchakarma Hospital to complete this clinical work. I also give my thanks to all my Panchakarma technicians and attendants, Hospital staffs, Laboratory staffs and all my Patients for their sincere support in this clinical trial.

\section{REFERENCES}

1. Agnivesh, Charak, Charaka Samhita: Edited with 'Charaka Chandrika' Hindi commentary by Dr. Brahmanand Tripathi, $4^{\text {th }}$ Edition, Chaukhambha Surbharati Prakashan, Varanasi, Vol-I, Ch.Vi.6/5, p 703

2. Harrison: Principals of Internal Medicine Vol. II, $14^{\text {th }}$ edition (International edition), Section-5, Chapter:385, p 2486-2490

3. Susruta, Sushruta Samhita: Edited by Kaviraj Ambikadatta Shastri, $11^{\text {th }}$ Edition, Chaukhambha Sanskrit Sansthan, Varanasi, Vol-II, Su.U.26/12, p 136

4. Agnivesh, Charak, Charaka Samhita: Edited with 'Charaka Chandrika' Hindi commentary by Dr. Brahmanand Tripathi, $4^{\text {th }}$ Edition, Chaukhambha Surbharati Prakashan, Varanasi, Vol-II., Ch.Chi.1/3/31, p 48

5. Sharma P. V. (1998): Dravya Guna Vijnana (V- II), Chaukhambha Bharti Academy, Varanasi, p 9-10

6. Agnivesh, Charak, Charaka Samhita: Edited with 'Charaka Chandrika' Hindi commentary by Dr. Brahmanand Tripathi, $4^{\text {th }}$ Edition, Chaukhambha Surbharati Prakashan, Varanasi, Vol-I, Ch.Ni.8/23, p 651

7. Diagnostic and Statistical Manual of Mental Disorders, $4^{\text {th }}$ Edition (DSM-IV) Published by American Psychiatric Association

8. Ayurvediya Panchakarma Vijnan: By H. S. Kasture, 8th edition. Published by Shri Vaidyanath Ayurved Bhawan Limited, p 119120. 2004

9. Website "www.ayurveda.com" of Dr. Vasant Lad, An Article on Shirodhara.

10. Website "www.docguide.com", A Special News on Generalized Anxiety Disorder by Cameron Johnston, London.

11. Website "www.thehimalayadrugco.com" of Himalaya Drugs Company, Banglore, An Article on Herbal Drug Sankhapuspi.

\section{Cite this article as:}

Ranjip Kumar Dass. A clinical study to compare the role of Jaladhara and Sankhapuspi rasayan in the management of Chittodvega (Anxiety disorders). Int. J. Res. Ayur. Pharm. 2012; 3(6):872-875 